\title{
Nightmares in Patients with Major Depressive Disorder, Bipolar Disorder, and Psychotic Disorders: A Systematic Review
}

\author{
Marine Ambar Akkaoui ${ }^{1,2,3, * \mathbb{C}}$, Michel Lejoyeux ${ }^{1,4}$, Marie-Pia d'Ortho ${ }^{5,6}$ \\ and Pierre A. Geoffroy ${ }^{1,4}$ (D) \\ 1 Department of Psychiatry and Addictive Medicine, Assistance Publique-Hôpitaux de Paris (AP-HP), \\ University Hospital Bichat, 46 rue Henri Huchard, 75018 Paris, France; michel.lejoyeux@aphp.fr (M.L.); \\ pierre.a.geoffroy@gmail.com (P.A.G.) \\ 2 Centre Psychiatrique d'Orientation et d'Accueil (CPOA), GHU Paris-Psychiatry \& Neurosciences, \\ 1 rue Cabanis, 75014 Paris, France \\ 3 Etablissement Publique de Santé Mentale de Ville Evrard, 202 Avenue Jean Jaurès Neuilly-Sur-Marne, \\ 93300 Neuilly-sur-Marne, France \\ 4 Université de Paris, 75018 Paris, France \\ 5 Université de Paris, NeuroDiderot, Inserm UMR1141, F-75019 Paris, France; marie-pia.dortho@aphp.fr \\ 6 Department of Physiology and Sleep Center, Assistance Publique-Hôpitaux de Paris (AP-HP), \\ University Hospital Bichat, 46 rue Henri Huchard, 75018 Paris, France \\ * Correspondence: marine.ambar@hotmail.com
}

Received: 8 October 2020; Accepted: 27 November 2020; Published: 9 December 2020

\begin{abstract}
Chronic nightmares are very common in psychiatric disorders, affecting up to $70 \%$ of patients with personality or post-traumatic stress disorders. In other psychiatric disorders, the relationships with nightmares are poorly known. This review aimed to clarify the relationship between nightmares and both mood and psychotic disorders. We performed a systematic literature search using the PubMed, Cochrane Library and PsycINFO databases until December 2019, to identify studies of patients suffering from either a mood disorder or a psychotic disorder associated with nightmares. From the 1145 articles screened, 24 were retained, including 9 studies with patients with mood disorders, 11 studies with patients with psychotic disorders and 4 studies with either psychotic or mood disorders. Nightmares were more frequent in individuals with mood or psychotic disorders than in healthy controls (more than two-fold). Patients with frequent nightmares had higher suicidality scores and had more frequently a history of suicide attempt. The distress associated with nightmares, rather than the frequency of nightmares, was associated with the severity of the psychiatric disorder. Further studies assessing whether nightmare treatment not only improves patient-sleep perception but also improves underlying psychiatric diseases are needed. In conclusion, nightmares are overrepresented in mood and psychotic disorders, with the frequency associated with suicidal behaviors and the distress associated with the psychiatric disorder severity. These findings emphasize major clinical and therapeutic implications.
\end{abstract}

Keywords: nightmare; bad dreams; sleep disorders; mood disorders; psychotic disorders; suicide

\section{Introduction}

Sleep disorders are often implicated in the clinical course of psychiatric disorders. Among these sleep disorders, insomnia and nightmares are very common in clinical practice associated with psychiatric disorders [1]. Nightmares are associated with increased psychological distress [1], worse physical health outcomes [2], and increased risk of self-harm and suicide [3,4]. Whereas episodic 
nightmares are very common with a prevalence of about $35-45 \%$ (one nightmare per month) [5-7], the prevalence of chronic nightmares is relatively low in the general population, ranging from $2-8 \%$ [5-10]. Nevertheless, the prevalence of these chronic nightmares seems significantly more frequent in individuals with psychiatric disorders [11]. Indeed, chronic nightmares are very common in psychiatric disorders, affecting up to $70 \%$ of patients with personality or post-traumatic stress disorders $[2,12,13]$. In other psychiatric disorders such as psychotic and mood disorders, which are very frequent, the relationships between nightmares and these disorders is poorly known. The prevalence of nightmares is consistent across several countries and cultures, including the United States, Canada, Europe, Japan, and Middle East [14]. The International Classification of Sleep Disorders, third edition (ICSD-3) defines nightmares as "coherent dream sequences that seem real and become increasingly more disturbing as they unfold. Emotions usually involve anxiety, fear or terror. The dream content most often focuses on imminent physical danger to the individual, but may also involve other distressing themes" $[15,16]$. Nightmares occur frequently in the context of REM sleep, and would usually awaken the sleeper, with a recollection of disturbing mental activity [10].

Episodic nightmares should be distinguished from a nightmare disorder. The fifth edition of the Diagnostic and Statistical Manual of Mental Disorders (DSM-5) [17] defines nightmare disorder according to five diagnostic criteria: (A) repeated occurrences of extended, extremely dysphoric and well-remembered dreams that generally occur during the second half of the major sleep episode; (B) the individual rapidly becomes oriented and alert on awakening from the dysphoric dreams; (C) the sleep disturbance causes clinically significant distress or impairment in social, occupational, or other important areas of functioning; (D) the nightmare symptoms are not attributable to the physiological effects of a substance; (E) coexisting mental and medical disorders do not explain the predominant complaint of dysphoric dreams. The DSM-5 specifies the nightmare disorder's duration: acute ( $<1$ month), sub-acute (more than 1 month but less than 6 months) or persistent ( $>6$ months). The DSM- 5 also specifies the severity of the disorder: severe (one episode per night) and moderate disorder (one or more episode per week).

Sleep complaints directly impact mental health and predict suicide attempts independently of all psychopathologies and sociodemographic characteristics [18]. More specifically, nightmares are overrepresented in almost all psychiatric disorders and are also associated with suicidal thoughts and behaviors, as well as suicide, independently of psychiatric disorders and symptoms [19-21]. Moreover, nightmares are also associated with other suicide risk factors, including hopelessness and depression [22,23] which predict suicidal ideation and behavior [24,25]. Nightmares seem to be more frequent in patients with major depressive disorders (MDD), bipolar disorders (BD), and schizophrenia than in the general population [26]. It has also been proposed that nightmares and psychotic symptoms represent a common domain with shared pathophysiology [27]. Nevertheless, some findings are controversial, including whether these associations correlate or not with the intensity of psychiatric symptoms, or if the frequency and/or the intensity of nightmares are associated with psychiatric disorders and suicidal behaviors. In addition, the question of whether nightmares are a specific or unspecific symptom shared by all or some psychiatric disorders still needs to be unraveled. Finally, although nightmares were associated with an increased risk of suicide in the general population, we wanted to clarify whether this association also exist in individuals with psychiatric disorders.

In this context and the absence of extensive reviews on mood and psychotic disorders, this systematic review aimed to clarify the association between nightmares and these psychiatric disorders by analyzing all studies assessing nightmares and mood disorders (major depressive disorders and bipolar disorders), and psychotic disorders (schizophrenic and non-schizophrenic disorders). The objective was to specify the prevalence of nightmares in patients with mood disorders or psychotic disorders, and their association with psychiatric manifestations and suicidal risk. 


\section{Methods}

We followed the Preferred Reporting Items for Systematic Reviews and Meta-analyses (PRISMA) [28] guidelines for the literature search and analysis.

\subsection{Eligibility Criteria}

We decided to include only studies examining mood or psychotic disorders because of their high prevalence and the absence of systematic reviews.

We included all studies meeting the following inclusion criteria: (A) must be an original paper (including case report, case study and case series, and epidemiological studies), (B) must have enrolled patients with a primary diagnosis of either: mood disorder (bipolar disorder or major depressive episode), psychotic disorder (schizophrenic and non-schizophrenic disorders), suicide, according to DSM or International Classification of Disease (ICD) criteria [17,29], and assessed by standardized scales, (C) must have studied nightmares, with any type of nightmare assessment, and (D) must study adolescents or adults over 18 years of age.

Studies were excluded if: (A) they enrolled patients with another primary psychiatric disorder (personality disorders, anxiety disorder, phobia, Post-Traumatic Stress Disorder (PTSD), eating disorder, attention-deficit hyperactivity disorder (ADHD), addictions, autism spectrum disorders) or non-psychiatric disorders (dementia, cognitive disorders), (B) they studied other parasomnias, (C) they were not in English or French, (D) patients were younger than 18 years old or older than 80 years old, (E) they were a systematic review or a meta-analysis, $(F)$ nightmares were induced by treatments, and (G) participants were selected from the general population.

\subsection{Search Strategy}

We searched on PubMed, Cochrane Library and PsycINFO and attempted to screen all the scientific literature until December 2019. The following terms were used for the literature search: ("nightmare" (All Fields) OR "dream" (All Fields) OR "parasomnia" (All Fields) OR "nightmare" (Medical Subject Headings (MeSH)Terms)) AND ("psychosis" (All Fields) OR "psychosis "(MeSH Terms) OR "hallucination" (All Fields) OR "schizophrenia" (All Fields) OR "bipolar disorder" (All Fields) OR "bipolar disorder" (MeSH Terms) OR "suicide" (All Fields) OR "suicide" (MeSH Terms) OR "depression" (All Fields) OR "major depressive episode" (All Fields) OR "depressive disorder" (All Fields) OR "depressive disorder" (MeSH Terms) OR "manic" (All Fields)). Relevant studies were identified and their reference lists were hand searched.

\subsection{Study Selection}

Two authors (M.A.A. and P.A.G.) independently screened for the titles of potentially eligible publications. Some papers were excluded at this stage (See Figure 1). After review of abstracts and papers, likely inclusions were assessed by MAA and PAG who independently extracted all information on age, sex, main diagnosis, nightmares frequency and distress, other comorbid sleep disorders and psychiatric disorders including post-traumatic stress symptoms and suicidality. 


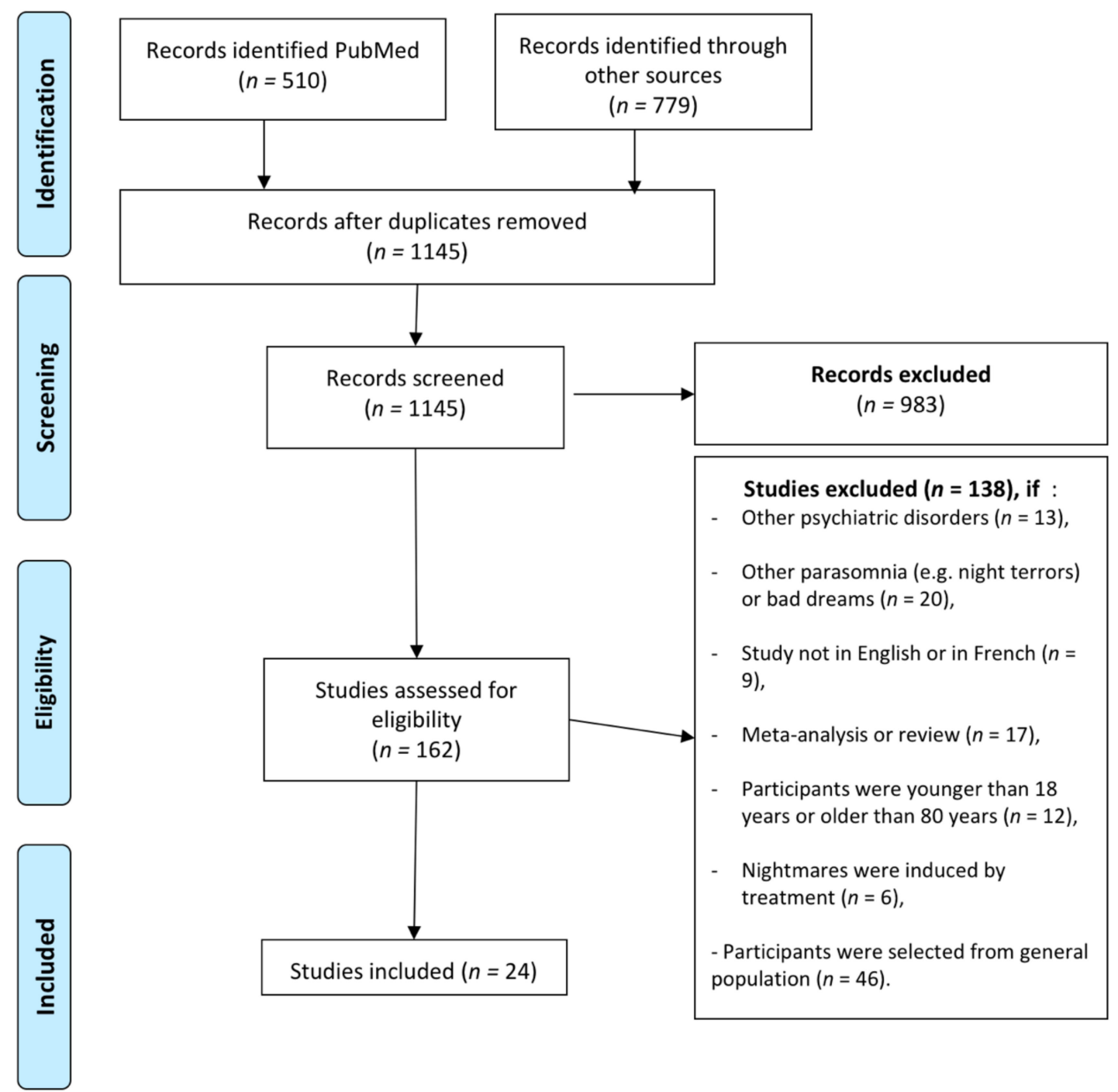

Figure 1. Flow diagram of nightmares and psychiatric disorders (mood and psychotic disorders) selection process.

\subsection{Frequent-Nightmare Definition}

As no consensus exists regarding frequent-nightmare definition, this definition varies considerably between studies. In the table, the frequency definitions used in reported studies are indicated as follow: ${ }^{*}$ Frequent nightmares were defined as $\geq 2 /$ week, ${ }^{* *}: \geq 1 /$ week, ${ }^{* * *}$ : monthly to weekly, ${ }^{* * * *}$ no definitions.

\section{Results}

Among the 1145 screened articles, 24 were included in this systematic review (Figure 1). The diagnostic criteria used in the retained studies, as well as the characteristics of studies that were included, are summarized in Tables 1-3. 
Table 1. Mood disorders and nightmares.

\begin{tabular}{|c|c|c|c|c|c|c|c|c|c|c|}
\hline Authors Years & $\begin{array}{c}\text { Study } \\
\text { Design }\end{array}$ & Aims & $n$ & $\begin{array}{c}\text { Age } \\
\text { (Years) }\end{array}$ & $\operatorname{Sex} F$ & $\begin{array}{l}\text { Diagnosis } \\
\text { Criteria for } \\
\text { Psychiatric } \\
\text { Disorder }\end{array}$ & $\begin{array}{l}\text { Nightmares: } \\
\text { Diagnosis and } \\
\text { Severity }\end{array}$ & $\begin{array}{c}\text { Other } \\
\text { Evaluation }\end{array}$ & Main Results & Comments \\
\hline Agargu, 1998 [29] & $\begin{array}{l}\text { Controlled } \\
\text { study }\end{array}$ & $\begin{array}{l}\text { To examine } \\
\text { the association } \\
\text { between repetitive } \\
\text { and frightening } \\
\text { dreams and suicidal } \\
\text { tendency in } \\
\text { patients with } \\
\text { major depression }\end{array}$ & MDD, $n=29$ & 31.6 & $69 \%(0)$ & $\begin{array}{l}\text { DSM-III-R } \\
\text { criteria for major } \\
\text { depression }\end{array}$ & $\begin{array}{l}\text { All patients received } \\
\text { an oral definition } \\
\text { of nightmare. } \\
\text { Nightmare frequency } \\
\text { Frequent nightmare } \\
\text { if } \geq 2 / \text { week }\end{array}$ & $\begin{array}{l}\text { SADS suicide } \\
\text { subscale } \geq 3 \\
\text { BDI }\end{array}$ & $\begin{array}{l}\text { Mean suicidality score was } \\
\text { higher in MDD patients with } \\
\text { nightmares than in the control } \\
\text { group: } 4.2 \text { vs. } 2.9 \text { in the second } \\
\text { group, } p=0.014 \text {. } \\
72 \% \text { of patients with } \\
\text { nightmares classified as being } \\
\text { suicidal vs. } 47 \% \text { in the } \\
\text { non-nightmare group. }\end{array}$ & $\begin{array}{l}\text { Controlled group: } \\
\text { depressed patients } \\
\text { with dreams but } \\
\text { no nightmares } \\
(n=31)\end{array}$ \\
\hline Agargun, 2003 [30] & $\begin{array}{l}\text { Cases } \\
\text { reports }\end{array}$ & $\begin{array}{l}\text { To discuss } \\
\text { relationship between } \\
\text { dreams and the first } \\
\text { episode of the illness } \\
\text { in term of mood } \\
\text { regulatory functions } \\
\text { of dream }\end{array}$ & $\mathrm{ME}, n=3$ & 29.0 & $\begin{array}{l}33.3 \% \\
(n=3)\end{array}$ & DSM-IV criteria & - & - & $\begin{array}{l}\text { All patients had one nightmare } \\
\text { before decompensation of their } \\
\text { first manic episode }\end{array}$ & \\
\hline Besiroglu, 2004 [31] & $\begin{array}{l}\text { Controlled } \\
\text { study }\end{array}$ & $\begin{array}{l}\text { To investigate } \\
\text { the relationship } \\
\text { between nightmares } \\
\text { ant terminal } \\
\text { insomnia un } \\
\text { unipolar depressed } \\
\text { patients with } \\
\text { melancholic features }\end{array}$ & $\begin{array}{l}\text { MDD, } n=82 \\
\text { (unipolar) }\end{array}$ & 32.4 & $\begin{array}{l}58.5 \% \\
(n=48)\end{array}$ & DSM-IV criteria & $\begin{array}{l}\text { All patients received } \\
\text { an oral definition } \\
\text { of nightmare. } \\
\text { Nightmare frequency } \\
\text { Frequent nightmare } \\
\text { if } \geq 2 / \text { week }\end{array}$ & $\begin{array}{l}\text { HDRS (items } \\
6,7 \text { and } 8 \text { for } \\
\text { insomnia) }\end{array}$ & $\begin{array}{l}\text { Nightmares were more } \\
\text { frequent in the melancholic } \\
\text { feature group }(90 \%, n=74), \\
\text { than in non-melancholic group } \\
(56 \%, n=42), p<0.001 \text {. } \\
\text { Nightmares were significantly } \\
\text { more frequent in the patients } \\
\text { with terminal insomnia than } \\
\text { without (regardless of } \\
\text { melancholic features): } 90.1 \% \text { vs. } \\
19.4 \% \text { respectively }(p<0.001) \text {. }\end{array}$ & $\begin{array}{l}\text { Controlled group: } \\
\text { depressed patients } \\
\text { without } \\
\text { melancholic } \\
\text { features }(n=75)\end{array}$ \\
\hline
\end{tabular}


Table 1. Cont

\begin{tabular}{|c|c|c|c|c|c|c|c|c|c|c|}
\hline Authors Years & $\begin{array}{l}\text { Study } \\
\text { Design }\end{array}$ & Aims & $n$ & $\begin{array}{c}\text { Age } \\
\text { (Years) }\end{array}$ & Sex $F$ & $\begin{array}{l}\text { Diagnosis } \\
\text { Criteria for } \\
\text { Psychiatric } \\
\text { Disorder }\end{array}$ & $\begin{array}{l}\text { Nightmares: } \\
\text { Diagnosis and } \\
\text { Severity }\end{array}$ & $\begin{array}{c}\text { Other } \\
\text { Evaluation }\end{array}$ & Main Results & Comments \\
\hline Agargun, 2007 [32] & $\begin{array}{l}\text { Controlled } \\
\text { study }\end{array}$ & $\begin{array}{l}\text { To examines the } \\
\text { relationship among } \\
\text { nightmares, suicide } \\
\text { attempts and } \\
\text { melancholic features } \\
\text { in unipolar major } \\
\text { depressed patients }\end{array}$ & $\mathrm{MDD}, n=100$ & 32.1 & $\begin{array}{l}51 \% \\
(n=51)\end{array}$ & DSM-IV criteria & $\begin{array}{l}\text { ICSD-R criteria. } \\
\text { All patients received } \\
\text { an oral definition of } \\
\text { nightmare } \\
\text { Nightmare frequency } \\
\text { Frequent nightmare if } \\
\geq 2 / \text { week }\end{array}$ & $\begin{array}{l}\text { Suicide } \\
\text { attempt } \\
\text { during current } \\
\text { episode }(\geq 1) \\
\text { HDRS (items } \\
6,7 \text { and } 8 \text { for } \\
\text { insomnia) }\end{array}$ & $\begin{array}{l}\text { MDD with melancholic } \\
\text { features: } 28 \% \text { (n) }(n=28) \text { suicide } \\
\text { attempt during current episode; } \\
\text { significant difference between } \\
\text { melancholic patients with and } \\
\text { without suicidal attempt in } \\
\text { terms of frequency of middle } \\
\text { and terminal insomnia and } \\
\text { nightmares (nightmares, } n=27 \\
(96 \%) \text { in suicide attempt group, } \\
\text { vs. } n=57(79 \%) \text { in non-suicide } \\
\text { attempt group }(p=0.036)) \text {. } \\
\text { No significant difference in the } \\
\text { non-melancholic group for } \\
\text { suicide attempt in term of } \\
\text { nightmares and insomnia. } \\
\text { Nightmares more common in } \\
\text { MDD with melancholic feature } \\
(n=84,84 \%) \text { than } \\
\text { non-melancholic features } \\
(n=28,57 \%) ; p=0.001 . \\
\text { Nightmares more frequent in } \\
\text { patients with suicidal attempt } \\
(n=33.86 \%), \text { than } \\
\text { non-attempters } \\
(n=79,71 \%) ; p=0.039 .\end{array}$ & $\begin{array}{l}\text { Controlled group: } \\
\text { depressed patients } \\
\text { without } \\
\text { melancholic } \\
\text { features }(n=49)\end{array}$ \\
\hline Thünker, 2012 [33] & Cohort & $\begin{array}{l}\text { To test the } \\
\text { effectiveness of } \\
\text { standardized } \\
\text { nightmare therapy } \\
\text { (based on IRT) in } \\
\text { patients suffering } \\
\text { from nightmares } \\
\text { only, or with } \\
\text { depression or PTSD. }\end{array}$ & MDD, $n=21$ & 30.0 & - & ND & $\begin{array}{l}\text { Self-questionnaire } \\
\text { (nightmare frequency, } \\
\text { anxiety during } \\
\text { nightmares and } \\
\text { daytime distress } \\
\text { (7-point scale)) }\end{array}$ & $\begin{array}{l}\text { Overall } \\
\text { improvement } \\
\text { of therapy on } \\
\text { a 7-point scale }\end{array}$ & $\begin{array}{l}\text { Decrease of nightmare } \\
\text { frequency after intervention in } \\
\text { MDD patients; decrease of } \\
\text { anxiety after intervention }\end{array}$ & $\begin{array}{l}8 \text { therapy session } \\
\text { of } 50 \text { min each }\end{array}$ \\
\hline
\end{tabular}


Table 1. Cont.

\begin{tabular}{|c|c|c|c|c|c|c|c|c|c|c|}
\hline Authors Years & $\begin{array}{c}\text { Study } \\
\text { Design }\end{array}$ & Aims & $n$ & $\begin{array}{c}\begin{array}{c}\text { Age } \\
\text { (Years) }\end{array}\end{array}$ & Sex F & $\begin{array}{l}\text { Diagnosis } \\
\text { Criteria for } \\
\text { Psychiatric } \\
\text { Disorder }\end{array}$ & $\begin{array}{l}\text { Nightmares: } \\
\text { Diagnosis and } \\
\text { Severity }\end{array}$ & $\begin{array}{c}\text { Other } \\
\text { Evaluation }\end{array}$ & Main Results & Comments \\
\hline Li, 2012 [34] & $\begin{array}{l}\text { Prospective } \\
\text { cohort }\end{array}$ & $\begin{array}{l}\text { To investigate the prevalence } \\
\text { and persistence of nocturnal } \\
\text { sleep symptoms, and } \\
\text { examine sociodemographic, } \\
\text { clinical and psychosocial } \\
\text { correlates of residual sleep } \\
\text { disturbances in remitted } \\
\text { depressed patients and } \\
\text { investigate association of } \\
\text { functional outcomes and } \\
\text { suicidal ideation with } \\
\text { residual sleep disturbances } \\
\text { in remitted } \\
\text { depressed patients. }\end{array}$ & 362 & 44.6 & $\begin{array}{l}81.7 \% \\
(n=296)\end{array}$ & ICD-10 criteria & $\begin{array}{l}\text { Sleep questionnaire } \\
\text { for insomnia and } \\
\text { nightmare } \\
\text { (5-point scale) } \\
\text { Nightmare Distress } \\
\text { Questionnaire (NDQ) }\end{array}$ & $\begin{array}{l}\text { Suicide } \\
\text { evaluation: } \\
\text { MINI } \\
\text { suicidality } \\
\text { module }\end{array}$ & $\begin{array}{l}\text { Patients with nightmares and } \\
\text { insomnia had fewer chance to } \\
\text { be in remission of MDD at } 4 \\
\text { years }(29.8 \% \text { of remission in } \\
\text { patients with nightmares } \\
(n=36) \text { vs. } 47.3 \% \text { of remission } \\
\text { in patients without nightmares } \\
(n=114), p<0.01) \text {. } \\
\text { Frequent nightmare at baseline } \\
\text { was significantly associated } \\
\text { with residual nightmare at } \\
\text { follow up (OR }=5.17,95 \% \text { CI } \\
(13.35-19.9)) \text { after controlling } \\
\text { for sociodemographic factors } \\
\text { and psychiatric comorbidity. } \\
\text { Suicidal ideation was } \\
\text { significantly associated with } \\
\text { residual nightmares } \\
(\text { OR }=8.40,95 \% \text { CI }(1.79-39.33)) \\
\text { after controlling for } \\
\text { confounding factors }\end{array}$ & $\begin{array}{l}\text { There were no } \\
\text { definition of } \\
\text { nightmares }\end{array}$ \\
\hline Marinova, 2014 [22] & Cohort & $\begin{array}{l}\text { To test the hypothesis that } \\
\text { nightmares are associated } \\
\text { with an elevated suicidal } \\
\text { risk in depressed patients }\end{array}$ & $\begin{array}{l}\mathrm{RDD}, \\
n=44 \\
\mathrm{BD}, n=8\end{array}$ & 24 to 75 & $\begin{array}{l}53.8 \% \\
(n=28)\end{array}$ & ICD-10 criteria & $\begin{array}{l}\text { Nightmare: defined as } \\
\text { unpleasant dream } \\
\text { Dream questionnaire } \\
\text { Nightmare yes/non } \\
\text { (no measure } \\
\text { of frequency) }\end{array}$ & $\begin{array}{l}\text { Question } 3 \text { of } \\
\text { HDRS for } \\
\text { suicidality }\end{array}$ & $\begin{array}{l}\text { Difference between RDD and } \\
\text { BD: } 64 \% \text { of RDD had } \\
\text { nightmares vs. } 25 \% \text { of BD } \\
(p<0.044) \text {. } \\
\text { In RDD subgroup, patients } \\
\text { with nightmares had } \\
\text { significantly higher average } \\
\text { score on the HDRS item on } \\
\text { suicide risk (2.36) than those } \\
\text { without nightmare (1.00), } \\
p<0.005 \text {. They had history of } \\
\text { suicide attempts significantly } \\
\text { more frequently ( } 35 \% \text { vs. } 6 \% \text {, } \\
p<0.05) \text {. No differences in the } \\
\text { BD subgroup. }\end{array}$ & $\begin{array}{l}\text { No differentiation } \\
\text { bad dreams and } \\
\text { nightmares }\end{array}$ \\
\hline Woo, 2014 [35] & $\begin{array}{l}\text { Case } \\
\text { report }\end{array}$ & $\begin{array}{l}\text { To describe EMDR treatment } \\
\text { of nightmare and highlights } \\
\text { various aspects of } \\
\text { EMDR therapy }\end{array}$ & $\begin{array}{l}\text { MDD, } \\
n=1\end{array}$ & 36 & $\begin{array}{l}100 \% \\
(n=1)\end{array}$ & $\begin{array}{l}\text { Clinical } \\
\text { examination }\end{array}$ & 4-5/weeks for 9 years & - & $\begin{array}{l}\text { Better after four } \\
\text { sessions of EMDR }\end{array}$ & - \\
\hline
\end{tabular}


Table 1. Cont.

\begin{tabular}{|c|c|c|c|c|c|c|c|c|c|c|}
\hline Authors Years & $\begin{array}{c}\text { Study } \\
\text { Design }\end{array}$ & Aims & $n$ & $\begin{array}{c}\text { Age } \\
\text { (Years) }\end{array}$ & Sex F & $\begin{array}{l}\text { Diagnosis } \\
\text { Criteria for } \\
\text { Psychiatric } \\
\text { Disorder }\end{array}$ & $\begin{array}{l}\text { Nightmares: } \\
\text { Diagnosis and } \\
\text { Severity }\end{array}$ & $\begin{array}{c}\text { Other } \\
\text { Evaluation }\end{array}$ & Main Results & Comments \\
\hline Lai, 2014 [36] & Cohort & $\begin{array}{l}\text { To examine whether patients } \\
\text { with } \mathrm{BD} \text { and MDD exhibit } \\
\text { different sleep problems and } \\
\text { to what extent their relatives } \\
\text { have sleep complaints }\end{array}$ & $\begin{array}{l}\mathrm{BD} \\
n=363 \\
\mathrm{MDD} \\
n=157\end{array}$ & $\begin{array}{l}35.5 \\
(\mathrm{BD}) \\
45.6 \\
(\mathrm{MDD})\end{array}$ & $\begin{array}{l}52.3 \% \\
(n=190) \text { for } \\
\text { BD, 68.9\% } \\
(n=108) \text { for } \\
\text { MDD }\end{array}$ & DSM-IV criteria & PSQI for sleep quality & - & $\begin{array}{l}\text { Frequent nightmares in } \\
\text { patients with MDD or BD were } \\
\text { associated to a higher risk of } \\
\text { suicidal ideations (OR }=2.88 \text { ) } \\
\text { and attempts (OR }=1.89 \text { ) after } \\
\text { adjustment for age at } \\
\text { interview and sex. }\end{array}$ & - \\
\hline
\end{tabular}

Table 1-Mood disorders and nightmares. F = Female; RDD = Recurrent Depressive Disorder; BD = Bipolar Disorder, MDD = Major Depressive Disorder; ME = Manic Episode; ND = No

Data; PSQI = Pittsburgh Sleep Quality Index; DSM = Diagnostic and Statistical Manual of Mental Disorders; ICD-10 = International Statistical Classification of Diseases and Related Health

Problems; SADS = Schedule for Affective Disorders and Schizophrenia; BDI: Beck Depression Inventory; HDRS: Hamilton Depression Rating Scale.

Table 2. Psychotic Disorders and nightmares.

\begin{tabular}{|c|c|c|c|c|c|c|c|c|c|c|}
\hline Authors Years & $\begin{array}{l}\text { Type of } \\
\text { Article }\end{array}$ & Aims & $n$ & Age (Years) & Sex F & $\begin{array}{l}\text { Diagnosis } \\
\text { Criteria }\end{array}$ & $\begin{array}{l}\text { Nightmares: } \\
\text { Diagnosis } \\
\text { and Severity }\end{array}$ & $\begin{array}{l}\text { Other } \\
\text { Evaluation }\end{array}$ & Main Results & Comments \\
\hline Shorkey, 1974 [37] & Case report & $\begin{array}{l}\text { Treatment of } \\
\text { recurrent nightmare } \\
\text { with desensitization }\end{array}$ & $\begin{array}{l}\text { Schizophrenia, } \\
n=1\end{array}$ & 38 & $0 \%(n=0)$ & $\begin{array}{l}\text { Clinical } \\
\text { examination }\end{array}$ & $\begin{array}{l}\text { Daily } \\
\text { nightmares }\end{array}$ & - & $\begin{array}{l}\text { In the nightmare, the devil was } \\
\text { a snake; treatment by } \\
\text { desensitization of fears of } \\
\text { snakes, with efficacy on } \\
\text { nightmares (no nightmares } \\
\text { avec } 2 \text { years follow up) }\end{array}$ & \\
\hline Fennig, 1992 [38] & Brief Report & $\begin{array}{l}\text { Presentation of a } \\
\text { patient which had a } \\
\text { transition from } \\
\text { nightmare to brief } \\
\text { psychotic episode }\end{array}$ & BPE, $n=1$ & 78 & $0 \%(n=0)$ & $\begin{array}{l}\text { Clinical } \\
\text { examination }\end{array}$ & $\begin{array}{l}\text { Recurrent } \\
\text { nightmare for } \\
3 \text { years }\end{array}$ & - & $\begin{array}{l}\text { Brief psychotic episode } \\
\text { occurring after a nightmare, } \\
\text { with same thematic; treatment } \\
\text { by TRIAZOLAM } 25 \mathrm{mg} / \mathrm{d} \text { and } \\
\text { OXAZEPAM } 20 \mathrm{mg} / \mathrm{d} \text { with no } \\
\text { recurrence after } 6 \mathrm{months} \\
\text { follow up }\end{array}$ & \\
\hline Levin, 1998 [39] & Case report & $\begin{array}{l}\text { To illustrate how } \\
\text { the nightmare may } \\
\text { presage the } \\
\text { underlying } \\
\text { psychological } \\
\text { disorganization } \\
\text { during the period } \\
\text { of psychic } \\
\text { decompensation }\end{array}$ & $\begin{array}{l}\text { Schizophrenia, } \\
n=1\end{array}$ & 40 & $\begin{array}{l}100 \% \\
(n=1)\end{array}$ & $\begin{array}{l}\text { DSM-IV } \\
\text { criteria }\end{array}$ & & - & $\begin{array}{l}\text { Insomnia and nightmare the } \\
\text { week before relapse; same } \\
\text { thematic of delusion and } \\
\text { hallucination, than in } \\
\text { nightmares preceding } \\
\text { decompensation. }\end{array}$ & $\begin{array}{l}\text { The patient } \\
\text { remained able to } \\
\text { differentiate her } \\
\text { nightmares from } \\
\text { her waking } \\
\text { hallucinations and } \\
\text { her waking life. }\end{array}$ \\
\hline
\end{tabular}


Table 2. Cont.

\begin{tabular}{|c|c|c|c|c|c|c|c|c|c|c|}
\hline Authors Years & $\begin{array}{l}\text { Type of } \\
\text { Article }\end{array}$ & Aims & $n$ & $\begin{array}{l}\text { Age } \\
\text { (Years) }\end{array}$ & Sex $F$ & $\begin{array}{l}\text { Diagnosis } \\
\text { Criteria }\end{array}$ & $\begin{array}{l}\text { Nightmares: } \\
\text { Diagnosis and } \\
\text { Severity }\end{array}$ & $\begin{array}{l}\text { Other } \\
\text { Evaluation }\end{array}$ & Main Results & Comments \\
\hline Lusignan, 2009 [40] & $\begin{array}{l}\text { Controlled } \\
\text { study }\end{array}$ & $\begin{array}{l}\text { To investigate dream } \\
\text { content in patients } \\
\text { with schizophrenia } \\
\text { using both } \\
\text { questionnaire and } \\
\text { laboratory REM } \\
\text { sleep awakenings }\end{array}$ & $\begin{array}{l}\text { Schizophrenia, } \\
n=14\end{array}$ & 25.5 & $(n=1)$ & $\begin{array}{l}\text { DSM-IV-TR } \\
\text { criteria }\end{array}$ & $\begin{array}{l}\text { Oral definition of } \\
\text { nightmares Dream } \\
\text { questionnaire } \\
\text { (11 items } \\
\text { self-report): } \\
\text { nightmare } \\
\text { frequency and } \\
\text { dream emotions }\end{array}$ & $\begin{array}{l}3 \text { consecutive } \\
\text { nights in sleep } \\
\text { laboratory; } \\
\text { dream report } \\
\text { collected } \\
\text { following } \\
\text { awakenings } \\
\text { from REM sleep }\end{array}$ & $\begin{array}{l}\text { Self-report questionnaire: } \\
\text { patients with schizophrenia } \\
\text { reported nightmares more } \\
\text { frequently (4.1 vs. 2.1, } \\
p=0.006) \text { and more nightmare } \\
\text { per year (22.8 vs. } 3.5, p=0.003) \text {. } \\
\text { No significant difference for } \\
\text { bad dreams, dream recall, lucid } \\
\text { dreaming, control of dreams } \\
\text { or physical sensation } \\
\text { during dreams. } \\
\text { Laboratory measures: } \\
92 \text { awakenings from REM } \\
\text { sleep, with } 78 \text { dream reports } \\
\text { (no difference between } \\
2 \text { groups in dream reports, } \\
\text { and white dream) }\end{array}$ & $\begin{array}{l}\text { Control group, } \\
n=15 \text {. } \\
\text { No difference in } \\
\text { polysomnographic } \\
\text { measures in } \\
\text { both groups. }\end{array}$ \\
\hline Michels, 2014 [41] & $\begin{array}{l}\text { Controlled } \\
\text { study }\end{array}$ & $\begin{array}{l}\text { To investigate } \\
\text { nightmare frequency } \\
\text { and its correlates in } \\
\text { patients with } \\
\text { schizophrenia }\end{array}$ & $\begin{array}{l}\text { Schizophrenia, } \\
n=17\end{array}$ & 32.9 & $47.0 \%(n=8)$ & ND & $\begin{array}{l}\text { DDNSI for } \\
\text { frequency of } \\
\text { nightmares } \\
(0=\text { never to } \\
7=\text { several times a } \\
\text { week) and } \\
\text { intensity (distress) }\end{array}$ & $\begin{array}{l}\text { ISI for insomnia } \\
\text { C-SSRS for } \\
\text { suicide } \\
\text { BDI }\end{array}$ & $\begin{array}{l}\text { Higher frequency of } \\
\text { nightmares in patients with } \\
\text { schizophrenia (3.65, } p=0.0145) \text {, } \\
\text { and ARMS patients } \\
\text { ( } 3.79, p=0.003) \text { than HC } \\
\text { No significant correlation } \\
\text { between BDI and } \\
\text { nightmare frequency } \\
\text { No significant correlation } \\
\text { between PANNS and } \\
\text { nightmare frequency }\end{array}$ & $\begin{array}{l}\text { Comparison with } 14 \\
\text { patients with at risk } \\
\text { mental states for } \\
\text { psychosis (ARMS) } \\
\text { and } 17 \text { healthy } \\
\text { relatives of patients }\end{array}$ \\
\hline Sheaves, 2015 [42] & Case series & $\begin{array}{l}\text { To assess the } \\
\text { acceptability and } \\
\text { feasibility of } \\
\text { Imagery Rehearsal } \\
\text { (IR) for the treatment } \\
\text { of nightmares in the } \\
\text { context of psychosis }\end{array}$ & $p, n=6$ & 39.7 & $66.6 \%(n=4)$ & ND & $\begin{array}{l}7 \text { points rating } \\
\text { scale for } \\
\text { nightmare } \\
\text { intensity, } \\
\text { vividness and } \\
\text { distress, and if } \\
\text { recurrent (yes/no) } \\
\text { Mean of } 4.4 \text { per } \\
\text { week }\end{array}$ & - & $\begin{array}{l}5 / 6 \text { participants attended } 4-6 \\
\text { sessions of IR. Mean nightmare } \\
\text { related distress across the week } \\
\text { decreased from } 5.43 \text { to } 4.28 ; \\
\text { improvement on vividness and } \\
\text { intensity of nightmares; no } \\
\text { decrease of nightmare } \\
\text { frequency, but patients } \\
\text { described a change in } \\
\text { emotional response. }\end{array}$ & $\begin{array}{l}\text { Participants with } \\
\text { PTSD were not } \\
\text { excluded from } \\
\text { the study } \\
\text { IR method: } \\
\text { psychoeducation, } \\
\text { collaboratively } \\
\text { planning a rescript } \\
\text { of the nightmare, } \\
\text { elaborating the } \\
\text { rescript with sensory } \\
\text { detail through } \\
\text { guided imagery and } \\
\text { daily practice of the } \\
\text { new dream script; } \\
4-6 \text { sessions }\end{array}$ \\
\hline
\end{tabular}


Table 2. Cont.

\begin{tabular}{|c|c|c|c|c|c|c|c|c|c|c|}
\hline Authors Years & $\begin{array}{l}\text { Type of } \\
\text { Article }\end{array}$ & Aims & $n$ & $\begin{array}{l}\text { Age } \\
\text { (Years) }\end{array}$ & Sex F & $\begin{array}{l}\text { Diagnosis } \\
\text { Criteria }\end{array}$ & $\begin{array}{l}\text { Nightmares: } \\
\text { Diagnosis and } \\
\text { Severity }\end{array}$ & $\begin{array}{l}\text { Other } \\
\text { Evaluation }\end{array}$ & Main Results & Comments \\
\hline Sheaves, 2015 [43] & Cohort & $\begin{array}{l}\text { To examine the } \\
\text { prevalence of } \\
\text { nightmares in people } \\
\text { with psychosis and to } \\
\text { describe the link } \\
\text { between nightmares } \\
\text { and sleep quality, } \\
\text { psychotic, , fffective } \\
\text { and cognitive } \\
\text { symptoms }\end{array}$ & $p, n=40$ & 41.9 & $\begin{array}{l}62.5 \% \\
(n=25)\end{array}$ & ND & $\begin{array}{l}\text { Nightmare frequency } \\
7 \text { points rating scale } \\
\text { for nightmare } \\
\text { intensity, vividness } \\
\text { and distress, and if } \\
\text { recurrent (yes/no) }\end{array}$ & $\begin{array}{l}\text { PSQI for } \\
\text { sleep quality }\end{array}$ & $\begin{array}{l}\text { At least one nightmare in the past } 14 \\
\text { nights in } \\
28 \text { patients }(70 \%) \text {. } \\
22 / 40(55.0 \%) \text { patients experienced at } \\
\text { least } \\
\text { weekly nightmares. } \\
\text { Nightmare frequency was associated } \\
\text { with poorer sleep: large positive } \\
\text { correlation between nightmare } \\
\text { frequency and PSQI while controlling for } \\
\text { antipsychotic dose; nightmare frequency } \\
\text { was negatively correlate with sleep } \\
\text { efficiency. } \\
\text { Nightmare distress, rather than } \\
\text { frequency, is a best account for the } \\
\text { association between nightmares and } \\
\text { daytime impairment: correlation } \\
\text { between nightmare distress and } \\
\text { delusional severity, depression, anxiety, } \\
\text { and stress. }\end{array}$ & $\begin{array}{l}n=17(42.5 \%) \text { of patients } \\
\text { screened positive for PTSD; } \\
11 / 17(65 \%) \text { reported } \\
\text { weekly nightmares. } \\
\text { This was not significantly } \\
\text { higher than the } 10 / 20(50 \%) \text { p } \\
\text { participants who reported } \\
\text { weekly nightmare } \\
\text { but did not screen } \\
\text { positive for PTSD. } \\
\text { No difference in nightmare } \\
\text { distress between PTSD and } \\
\text { without PTSD. }\end{array}$ \\
\hline Chiu, 2016 [44] & Cohort & $\begin{array}{l}\text { To explore the lived } \\
\text { experience of sleep } \\
\text { problems in people } \\
\text { with } \\
\text { schizophrenia-spectrum } \\
\text { disorders }\end{array}$ & 14 & ND & $50 \%(n=7)$ & ND & & - & $\begin{array}{l}n=7(50 \%) \text { of patients } \\
\text { reported nightmares }\end{array}$ & - \\
\hline Li, 2016 [45] & Cohort & $\begin{array}{l}\text { To examine the } \\
\text { prevalence of sleep } \\
\text { disturbances, } \\
\text { particularly frequent } \\
\text { insomnia and } \\
\text { nightmares, and their } \\
\text { prospective } \\
\text { associations with the } \\
\text { risk of suicide } \\
\text { attempts in patients } \\
\text { with schizophrenia } \\
\text { spectrum disorder }\end{array}$ & $\begin{array}{l}p, n=388 \\
\text { (Schizophrenia } \\
n=308 \text { ) }\end{array}$ & 41.0 & $\begin{array}{l}54.9 \% \\
(n=213)\end{array}$ & $\begin{array}{l}\text { ICD-10 } \\
\text { criteria }\end{array}$ & $\begin{array}{l}\text { Frequent nightmare } \\
\text { was defined as } \\
\text { having nightmares of } \\
\text { at least once a week } \\
\text { in the past year } \\
\text { Sleep questionnaire } \\
\text { for insomnia and } \\
\text { nightmares (5-point } \\
\text { scale for frequency) }\end{array}$ & - & $\begin{array}{l}\text { At baseline: } 19.3 \% \text { frequent } \\
\text { insomnia and } 9.0 \% \\
\text { frequent nightmares. } \\
\text { Comorbid insomnia and } \\
\text { nightmare reported in } 3.4 \% \text {. } \\
\text { Patients with frequent nightmare were } \\
\text { more likely to report frequent insomnia } \\
(37.1 \% \text { vs. } 17.6 \% \text {, } p<0.01) \text {. } \\
\text { Patients with frequent insomnia were } \\
\text { more likely to have comorbid } \\
\text { nightmare disturbances }(17.3 \% \text {, vs. } \\
7.0 \%, p<0.01) \text {. } \\
\text { The complaint of frequent nightmares } \\
\text { was associated with a lifetime history of } \\
\text { suicide attempts ( } 42.9 \% \text { vs. } 19.3 \%) \text {; it did } \\
\text { not predict an increased risk of suicide } \\
\text { attempt over the } \\
\text { follow up period. }\end{array}$ & $\begin{array}{l}8 \text { years observational study } \\
\text { on consecutively } \\
\text { recruited cohort } \\
\text { of psychiatric outpatients } \\
\text { with schizophrenia } \\
\text { spectrum diagnosis } \\
\text { Comorbidity of insomnia } \\
\text { and nightmare } \\
\text { disturbances was } \\
\text { significantly associated } \\
\text { with an increased risk of } \\
\text { suicide attempts, } \\
\text { not only in lifetime } \\
(p<0.001) \text {, but also during } \\
\text { the } 8 \text { years follow up period } \\
(p<0.01) \text {. }\end{array}$ \\
\hline
\end{tabular}


Table 2. Cont

\begin{tabular}{|c|c|c|c|c|c|c|c|c|c|c|}
\hline Authors Years & $\begin{array}{l}\text { Type of } \\
\text { Article }\end{array}$ & Aims & $n$ & $\begin{array}{l}\text { Age } \\
\text { (Years) }\end{array}$ & Sex F & $\begin{array}{l}\text { Diagnosis } \\
\text { Criteria }\end{array}$ & $\begin{array}{l}\text { Nightmares: } \\
\text { Diagnosis } \\
\text { and Severity }\end{array}$ & $\begin{array}{l}\text { Other } \\
\text { Evaluation }\end{array}$ & Main Results & Comments \\
\hline Reeve, 2018 [46] & Cohort & $\begin{array}{l}\text { To report on the } \\
\text { presence, severity } \\
\text { and treatment of } \\
\text { sleep disorders in } \\
\text { patients with } \\
\text { non-affective } \\
\text { psychosis }\end{array}$ & $p, n=60$ & 23.7 & $\begin{array}{l}35.0 \% \\
(n=21)\end{array}$ & DSM-5 & $\begin{array}{l}\text { ICSD-2, } \\
\text { ICSD-3 } \\
\text { Diagnostic } \\
\text { Interview for } \\
\text { Sleep Patterns } \\
\text { and Disorders }\end{array}$ & $\begin{array}{l}\text { Actigraphy } \\
\text { (wrist-based } \\
\text { activity } \\
\text { monitoring } \\
\text { device) and } \\
\text { sleep diary } \\
\text { for } 7 \text { days }\end{array}$ & $\begin{array}{l}80 \%(n=48) \text { of participants received } \\
\text { a positive screen or diagnosis for at } \\
\text { least one sleep disorder: insomnia } \\
\text { was the most frequent }(n=30.50 \%) \text {, } \\
\text { then nightmare }(n=29,48.3 \%) \text {. } \\
\text { Comorbidity: average of } 3.3 \text { sleep } \\
\text { disorder per patient. } n=30(33 \%) \\
\text { had bot insomnia and nightmares. } \\
\text { Severity of nightmares: Mild } n=2 \\
(6.9 \%) \text {, moderate } n=11(37.9 \%), \\
\text { severe } n=16(55.2 \%) ; \text { Night terror, } \\
\text { nightmare disorder and RLS were } \\
\text { the disorders least commonly } \\
\text { discussed with a clinician }(50 \%) \text {. }\end{array}$ & $\begin{array}{l}\text { No significantly } \\
\text { difference in } \\
\text { antipsychotic dose } \\
\text { between patients with } \\
\text { and without } \\
\text { nightmares. }\end{array}$ \\
\hline Sheave, 2019 [47] & $\begin{array}{l}\text { Randomized } \\
\text { Control trial }\end{array}$ & $\begin{array}{l}\text { To test the potential } \\
\text { benefits of } \\
\text { imagery focused } \\
\text { cognitive behavioral } \\
\text { therapy (CBT) } \\
\text { for nightmares } \\
\text { on nightmare } \\
\text { severity and } \\
\text { persecutory } \\
\text { delusions. }\end{array}$ & $\begin{array}{l}24 \text { patients } \\
\text { with weekly } \\
\text { nightmares and } \\
\text { persecutory } \\
\text { delusions in the } \\
\text { context of a } \\
\text { diagnosis of } \\
\text { non-affective } \\
\text { psychosis. }\end{array}$ & 41.0 & $\begin{array}{l}42 \% \\
(n=10)\end{array}$ & & $\begin{array}{l}\text { DDNSI } \\
\text { Sleep } \\
\text { Condition } \\
\text { Indicator (SCI) }\end{array}$ & $\begin{array}{l}\text { PSQI for } \\
\text { sleep quality }\end{array}$ & $\begin{array}{l}\text { Large effect size reductions in } \\
\text { nightmares and insomnia post } \\
\text { treatment ( } 4 \text { weeks) } \\
\text { (DDNSI } \mathrm{d}=-1.06 \text {; SCI d }=-1.4) \\
\text { maintained at follow up }(8 \text { weeks). } \\
\text { Post-treatment improvements were } \\
\text { observed in paranoia (GPTS), } \\
\text { affective symptoms (DASS-21), } \\
\text { dissociation (DES-B), and emotional } \\
\text { wellbeing (WEMWBS). } \\
\text { There were no changes in } \\
\text { hallucinations (CAPS) or activity } \\
\text { levels (time budget). }\end{array}$ & $\begin{array}{l}12 \text { treatment, } \\
12 \text { control. } \\
\text { Core technique was } \\
\text { imagery rehearsal } \\
\text { training. Additional } \\
\text { strategies included: } \\
\text { psychoeducation about } \\
\text { nightmares, reducing } \\
\text { pre-sleep hyperarousal, } \\
\text { increasing coping skills, } \\
\text { reducing preoccupation } \\
\text { with nightmares, } \\
\text { stabilizing REM sleep. }\end{array}$ \\
\hline
\end{tabular}
BPE = Brief Psychotic Episode; ND = No Data, $p=$ Psychosis; PSQI = Pittsburgh Sleep Quality Index; ARMS: at risk mental states for psychosis; BDI: Beck Depression Inventory,
DDNSI: Disturbing Dreams and Nightmare Severity Index; ISI: Insomnia Severity Index; C-SSRS: Columbia suicide rating scale. 
Table 3. Studies comparing psychiatric disorders and nightmares

\begin{tabular}{|c|c|c|c|c|c|c|c|c|c|}
\hline Authors Years & $\begin{array}{l}\text { Type of } \\
\text { Article }\end{array}$ & Aims & Diagnosis & $n$ & Age (Years) & Sex F & $\begin{array}{c}\text { Diagnosis } \\
\text { Criteria }\end{array}$ & Nightmares & Main Results \\
\hline Sjöström, 2007 [48] & Cohort & $\begin{array}{l}\text { To examine the } \\
\text { prevalence of specific } \\
\text { sleep disturbances in } \\
\text { suicide attempters and } \\
\text { to test the associations } \\
\text { between specific sleep } \\
\text { disturbances and } \\
\text { suicidality }\end{array}$ & $\begin{array}{l}\text { MDD, } n=55(33.3 \%) \text {, other } \\
\text { depression } n=20(12.1 \%) ; \\
\text { psychotic disorder } n=11 \\
(6.6 \%) \text {, alcohol/substance } \\
\text { misuse disorder } n=41 \\
\text { (24.8\%); anxiety disorder } \\
\text { and other disturbance } \\
n=27(16.3 \%)\end{array}$ & 165 & 35.3 & $\begin{array}{l}78 \% \\
(n=129)\end{array}$ & DSM-IV & $\begin{array}{l}\text { How often do } \\
\text { you experience } \\
\text { nightmare from } \\
1 \text { to } 5 \\
\text { Uppsala Sleep } \\
\text { Inventory (USI) for } \\
\text { sleep disturbance }\end{array}$ & $\begin{array}{l}\text { Frequent nightmares were less } \\
\text { common in patients who scored } 0 \\
\text { on all } 5 \text { suicidality items }(12 \%) \\
\text { than in those scoring } \geq 1 \text { on any } \\
\text { suicidality item }(45 \%) ; p<0.001\end{array}$ \\
\hline Sjöström, 2009 [19] & $\begin{array}{l}\text { Prospective } \\
\text { cohort }\end{array}$ & $\begin{array}{l}\text { To determine whether } \\
\text { those who reported } \\
\text { sleep disturbances in } \\
\text { general and frequent } \\
\text { nightmares in particular } \\
\text { were at increased risk of } \\
\text { repeat suicide attempt }\end{array}$ & $\begin{array}{l}\text { MDD, } n=55(33.3 \%) \text {, other } \\
\text { depression } n=20(12.1 \%) ; \\
\text { psychotic disorder } n=11 \\
(6.6 \%) \text {, alcohol/substance } \\
\text { misuse disorder } n=41 \\
\text { (24.8\%); anxiety disorder } \\
\text { and other disturbance } \\
n=27(16.3 \%)\end{array}$ & 165 & 35.3 & $\begin{array}{l}78 \% \\
(n=129)\end{array}$ & DSM-IV & $\begin{array}{l}\text { How often do you } \\
\text { experience } \\
\text { nightmare from } \\
1 \text { to } 5\end{array}$ & $\begin{array}{l}\text { Repeaters had more frequent } \\
\text { nightmare than non-repeaters } \\
(n=22(52 \%) \text { vs. } n=26(30 \%), \\
p=0.002) .98 \text { patients completed a } \\
2 \text { month follow up: persistent } \\
\text { nightmare were about } 3 \text { times } \\
\text { more common in repeaters }(n=13 \\
(46 \%), \text { vs. } n=10(14 \%) p=0.001)\end{array}$ \\
\hline Mume, 2009 [25] & $\begin{array}{l}\text { Controlled } \\
\text { study }\end{array}$ & $\begin{array}{l}\text { To highlight nightmare } \\
\text { in healthy individuals } \\
\text { and to demonstrate its } \\
\text { possible association } \\
\text { with psychopathology, } \\
\text { using schizophrenia } \\
\text { and depressive episode } \\
\text { as examples }\end{array}$ & $\begin{array}{l}\text { Schizophrenia }(n=54), \\
\text { major depressive disorder } \\
(n=40)\end{array}$ & 94 & $\begin{array}{l}42.6 \\
\text { (schizophrenic } \\
\text { patients), } 43.1 \\
\text { (MDD patients) }\end{array}$ & - & - & $\begin{array}{l}\text { Did you experience } \\
\text { nightmare in the } \\
\text { past one year? } \\
\text { Yes/No/ } \\
\text { if yes, how many } \\
\text { times did you } \\
\text { experience it in the } \\
\text { past one year? }\end{array}$ & $\begin{array}{l}\text { 9/54 }(16.7 \%) \text { of schizophrenic } \\
\text { patients experienced nightmare in } \\
\text { the previous years, and } 7 / 40 \\
(17.5 \%) \text { MDD patients } \\
\text { (vs } 6 / 123(4.9 \%) \mathrm{HC}) \text {. } \\
\text { Significantly more frequent in } \\
\text { psychiatric patients }(17 \%) \\
\text { than } \mathrm{HC}(p=0.0007) ; \\
\text { no significant difference between } \\
\text { schizophrenic and MDD patients. } \\
\text { Number of nightmare } \\
\text { schizophrenic patients mean } 42.7 \\
(\text { sd }=6.3) ; 44.6(\mathrm{sd}=5.9) \text { for MDD, } \\
\text { and } 18(\mathrm{sd}=6.6) \text { for } \mathrm{HC}, p<0.05 .\end{array}$ \\
\hline Lamis, 2018 [49] & Cohort & $\begin{array}{l}\text { To test the hopelessness } \\
\text { theory of suicide risk in } \\
\text { psychiatric patients who } \\
\text { may or may not } \\
\text { experiencing } \\
\text { nightmares. }\end{array}$ & $\begin{array}{l}\text { Non-affective psychosis } \\
(23.3 \%), \text { Bipolar I }(26.2 \%) \text {, } \\
\text { bipolar II }(3.5 \%), \\
\text { MDD }(11.6 \%), \\
\text { schizoaffective } \\
\text { disorder }(23.3 \%) \text {, } \\
\text { other }(12.8 \%)\end{array}$ & 172 & 39.15 & $n=91$ & $\begin{array}{l}\text { DSM-IV-TR } \\
\text { criteria + MINI } \\
\text { Beck } \\
\text { Hopelessness } \\
\text { Scale (BHS) }\end{array}$ & $\begin{array}{l}\text { DDNSI for } \\
\text { frequency and } \\
\text { severity of } \\
\text { nightmares. }\end{array}$ & $\begin{array}{l}\text { Patients who reported monthly to } \\
\text { weekly nightmares (compared to } \\
\text { patients who reported yearly or no } \\
\text { nightmare) were younger and } \\
\text { more likely to have been } \\
\text { hospitalized for a } \\
\text { recent suicide attempt. } \\
\text { They also had higher scores on } \\
\text { BHS and MINI suicide risk. } \\
\text { Severe hopelessness in } 44 \% \text { of } \\
\text { frequent nightmares vs. } 22.6 \%\end{array}$ \\
\hline
\end{tabular}

$\mathrm{F}=$ Female, $\mathrm{MDD}=$ Major Depressive Disorder; ND: no data. 
The results were separated into four categories: prevalence, association with symptoms, association with suicide, and treatment.

\subsection{Nightmares and Mood Disorders}

We found nine studies on nightmares and mood disorders (Table 1).

\subsubsection{Major Depressive Disorders (MDD)}

Nightmare Frequency in MDD

Few studies have estimated the prevalence of nightmares in patients suffering from MDD. One study found that patients with MDD experienced nightmares more than twofold than healthy controls (mean of 44.6 nightmares per year in patients with MDD, versus 18 nightmares per year in healthy controls; the prevalence of nightmares was $16.7 \%$ and $4.9 \%$, respectively) [25].

\section{Suicidality and Nightmare in MDD}

Patients with MDD and nightmares seem to have a higher risk of suicidality than MDD patients without nightmares. Agargun et al. found a significantly higher suicidality scores in patients with MDD and nightmares than without nightmares [29]. They also found, in a subgroup analysis, that this difference was significant in women, but not in men. In another study, Agargun et al. [32] found that nightmares were more frequent in MDD patients with suicidal attempts than in those without suicidal attempts ( $86 \%$ vs. $71 \%$ respectively). Marinova et al. explored the suicide risk in patients with unipolar recurrent depression and confirmed that patients with nightmares had a significantly higher suicidal score than those without nightmares (2.36 vs. 1.00 on the Hamilton Depression Rating Scale (HDRS) subscale for suicide) and had significantly more frequently a history of suicide attempt (35\% vs. $6 \%)$ [22].

Nightmares and MDD Symptoms

Patients were more likely to experience frequent nightmares ( $\leq 2 /$ week) when they had a MDD with melancholic features than without nightmares (respectively $90 \%$ of nightmares vs. 56\%) [31]. Moreover, in the same study, nightmares were significantly more frequent in depressed patients with terminal insomnia (e.g., "early morning waking") than without insomnia, regardless of melancholic features ( $90.1 \%$ vs. $19.4 \%$ respectively) [31].

Agargun et al. [32] studied 100 patients with melancholic features, and observed an increased frequency of nightmares and of middle and terminal insomnia in patients who committed a suicide attempt than those without suicide attempt (nightmares, $n=27$ e.g., $96 \%$ in suicide attempt group, vs. $n=57$ e.g., $79 \%$ in the non-suicide attempt group). The authors found no significant differences in non-melancholic depressed patients for suicide attempt, both for nightmares and insomnia. Moreover, nightmares were more common in major depressed patients with melancholic features $(84 \%)$ than without melancholic features $(57 \%)$.

\section{Treatment of Nightmares in MDD}

Thünker et al. [33] tested the effectiveness of standardized nightmare therapy based on image rehearsal therapy (IRT), in MDD patients suffering from nightmares, and showed a decrease in the nightmare frequency. Woo et al. [35] found an improvement for nightmares in MDD patients after four sessions of eye movement desensitization and reprocessing (EMDR). Li et al. [34] found that MDD patients with nightmares and insomnia had fewer chances to be in remission at four years of MDD ( $29.8 \%$ of remission in patients with nightmares vs. $47.3 \%$ in patients without nightmares). Moreover, they found that residual nightmares, but not residual insomnia, were significantly associated with suicidal ideation in patients remitted from major depressive disorders. 


\subsubsection{Bi-Polar Disorders}

Marinova et al. [22] tested the hypothesis that nightmares were associated with an elevated suicidal risk in depressed patient, differentiating bipolar depression from recurrent depression. They found a significantly higher frequency of nightmares in unipolar- than in bipolar-depression ( $64 \%$ vs. $25 \%$ ). There were no differences in the bipolar depression group for the suicide risk in patients with nightmares, compared with those without nightmares. However, the sample of depressed patients with bipolar disorder was small ( $n=8$ patients), which may explain the absence of significant results despite the large differences of frequencies reported. Lai et al. [36] also found that frequent nightmares (not defined) in bipolar or unipolar depression were associated with a higher risk of suicidal ideation $(\mathrm{OR}=2.88)$ and attempts $(\mathrm{OR}=1.89)$, after adjustment for age and sex.

Of notice, the scientific literature is very poor regarding nightmares and mania. Only one study [30] reported nightmares in three patients suffering from a first manic episode. The three patients reported at least one prodromal nightmare before their first episode [30].

\subsection{Nightmares and Psychotic Disorders}

We found 11 studies on nightmares and psychotic disorders (Table 2).

\subsubsection{Nightmare Frequency in Psychotic Disorders}

Nightmares are the second most frequent sleep disorder in patients with psychotic disorders, after insomnia, with a prevalence of frequent nightmares (defined as $\leq 1 /$ week) ranging from $9.0 \%$ to $55 \%[45,46]$. Insomnia and nightmares were frequently comorbid in patients with psychotic disorders. Accordingly, patients who had frequent nightmares (defined a $\leq 1 /$ week) were more likely to report frequent insomnia (37.1\% vs. $17.6 \%$ ). No data examined whether the severity of insomnia symptoms correlates or not with nightmare frequency or intensity.

\subsubsection{Nightmares and Psychotic Symptoms}

Fennig et al. [38] reported the case of a 78 year old patient, which saw a transition from a nightmare to a brief psychotic episode. The delirium had the same thematic as his recurrent nightmare of the last three years. He was treated with neuroleptics, with no recurrences of nightmare after six months of follow up. Another case report [39] found an association between decompensation and nightmares in a 40 year old woman suffering from schizophrenia: she had insomnia and nightmares the week before relapse, with the same thematic of delusion and hallucination as in her nightmares.

Three studies found that patients with schizophrenia reported nightmares significantly more frequently than healthy controls [26,41,42]. Moreover, patients with schizophrenia had a higher score of distress related to nightmares than healthy controls [41]. Neither significant correlations between nightmare frequency and intensity of psychotic symptoms measured by the Positive And Negative Syndrome Scale (PANNS), nor correlations for depressive symptoms (Beck scale for depression) and nightmare frequency were found in those patients with schizophrenia [41]. However, nightmare distress, rather than nightmare frequency, was correlated with delusional severity, depression, anxiety, and stress [43].

One study found in exploratory measures in fourteen patients with at-risk mental states for psychosis (ARMS) that they experienced significantly more nightmares compared to healthy controls [41], even ARMS patients who did not receive any treatment.

\subsubsection{Suicidality and Nightmares in Psychotic Disorders}

In one study [45], nightmare frequency was associated with a lifetime history of suicide attempts but did not predict an increased risk of suicide attempt over the eight years follow up period. In the same study, insomnia and nightmare were significantly associated with an increased risk of suicide attempts (lifetime history and during the follow-up period) [45]. 


\subsubsection{Treatment of Nightmares in Psychotic Disorders}

One case report [37] was of a 38 year old patient with schizophrenia. The patient had daily nightmares about the devil in the shape of a snake. The patient was treated by desensitization of the fear of snakes, with good efficacy on nightmares. This treatment efficacy was maintained over time, and the patient did not experience any nightmares during the two years follow-up [37].

Sheaves and al. [42] experienced imagery rehearsal therapy (IRT) - a cognitive-behavioral treatment for reducing the frequency and intensity of nightmares-for the treatment of nightmares in the context of psychosis in six patients, and observed an improvement on vividness and intensity of nightmares, without a decrease in nightmare frequency. One other non-randomized study found efficacy of IRT on the emotional response of nightmares in psychotic patients [50]. Interestingly, one pilot randomized clinical trial has evaluated IRT to reduce nightmare severity in 24 patients with persecutory delusions, with large size effect improvements in nightmare severity and insomnia [47]. In addition to IRT, the intervention included cognitive behavioral therapy techniques to target identified causal factors for nightmares. Large effect size improvements in nightmare severity and insomnia were reported post-treatment (4-weeks) and maintained at follow-up (8-weeks) [47].

\subsection{Study Comparing MDD and Schizophrenic Patients}

We found four additional studies comparing different psychiatric disorders regarding nightmares (Table 3).

One study [25] compared nightmare frequency in MDD and schizophrenic patients with a population without psychiatric disorders and found that nightmares were significantly more frequent in psychiatric patients, but did not find any differences between MDD and schizophrenic patients (respectively $17 \%$ and $4.9 \%$ in patients with psychiatric disorders and healthy controls).

In one cohort study [48] with 165 patients (33.3\% MDD, $6.6 \%$ psychotic disorder, $24.8 \%$ alcohol/substance misuse disorder, and $16.3 \%$ anxiety disorder), frequent nightmares (not defined) were more present in patients with a higher score of suicidality irrespective of underlying psychiatric disorder. Another study [19] conducted in the same cohort of patients found that patients with more than one suicide attempt had more frequent nightmares than those with one unique suicide attempt. Moreover, after a two-month follow-up, patients with more than one suicide attempt were more likely to have persistent nightmares during the follow-up period ( $46 \%$ vs. $14 \%$ respectively).

More recently, Lamis et al. [49], in a cohort of 172 patients with bipolar disorders $(29.7 \%)$, MDD (11.6\%), and psychotic disorders (46.6\%), found that patients who reported nightmares (defined as weekly to monthly), compared to patient who reported yearly or no nightmares, were younger and more likely to have been hospitalized for a recent suicide attempt, with no differences between these psychiatric disorders.

\section{Discussion}

Nightmares were more frequent in individuals with mood disorders and psychotic disorders [26,42] than in individuals without psychiatric disorders. This is concordant with the observed higher prevalence of sleep complaints in psychiatric patients than in the general population [51]. Table 4 summarizes key findings from this systematic review of nightmares in mood and psychotic disorders (Table 4). 
Table 4. Synthesis of the findings from the literature.

\begin{tabular}{|c|c|c|c|c|}
\hline & & & Main Results Regarding Nightmares & Studies \\
\hline \multirow{12}{*}{$\begin{array}{l}\text { Mood } \\
\text { disorders }\end{array}$} & \multirow{11}{*}{ Depression } & \multirow{3}{*}{ Frequency } & \multirow{2}{*}{$\begin{array}{l}\text { - Nightmares are more frequent in patients with MDD and melancholic } \\
\text { features than without. }\end{array}$} & Besiroglu, 2004 [31] \\
\hline & & & & Agargun 2007 [32] \\
\hline & & & - Nightmares are more frequent in unipolar depression than bipolar depression & Marinova, 2014 [22] \\
\hline & & \multirow{5}{*}{ Suicide } & - Higher suicidality score in MDD patients with frequent nightmares * than without & Agargun, 1998 [29] \\
\hline & & & - More suicidal ideation in MDD patients with frequent nightmares ** than without & Li, 2012 [34] \\
\hline & & & $\begin{array}{l}\text { - More suicidal attempts in MDD patients with melancholic features with frequent } \\
\text { nightmares * than without }\end{array}$ & Agargun 2007 [32] \\
\hline & & & \multirow{2}{*}{$\begin{array}{l}\text { - More suicidal ideation and attempts in unipolar MDD and bipolar MDD in patients } \\
\text { with frequent nightmares }\end{array}$} & Lai, 2014 [36] \\
\hline & & & & Marinova, 2014 [22] \\
\hline & & \multirow{2}{*}{ Treatment } & - Decrease of nightmare frequency and anxiety after IRT intervention in MDD patients & Thünker, 2012 [33] \\
\hline & & & - Improvement of nightmare frequency inn $36 \mathrm{MDD}$ patients after four sessions of EMDR & Woo, 2014 [35] \\
\hline & & Evolution & $\begin{array}{l}\text { - Patients with frequent nightmares }{ }^{* *} \text { were less in remission at four years than those } \\
\text { without nightmares }\end{array}$ & $\mathrm{Li}, 2012[34]$ \\
\hline & Mania & & - Three patients had nightmares as prodromal symptoms of their first manic episode & Agargun, $2003[30]$ \\
\hline \multirow{7}{*}{$\begin{array}{l}\text { Psychotic } \\
\text { disorders }\end{array}$} & & \multirow{7}{*}{ Frequency } & \multirow{2}{*}{ - Nightmares are more frequent in patient with schizophrenia than in healthy controls } & Lusignan, 2009 [40] \\
\hline & & & & Michels, 2014 [41] \\
\hline & & & \multirow{3}{*}{ - Frequency of frequent nightmares ${ }^{* *}$ ranging from 9 to $55 \%$} & Sheaves, 2015 [43] \\
\hline & & & & Chiu, 2016 [44] \\
\hline & & & & Li, 2016 [45] \\
\hline & & & $\begin{array}{l}\text { - Comorbid insomnia and nightmares are frequent in schizophrenia } \\
\circ \text { Patients with frequent nightmares }{ }^{* *} \text { were more likely to report frequentinsomnia } \\
\circ \text { Patients with frequent insomnia were more likely to have comorbid nightmares }\end{array}$ & $\mathrm{Li}, 2016[45]$ \\
\hline & & & $\begin{array}{l}\text { - Nightmares are the second most frequent sleep disorder, after insomnia, in patients } \\
\text { with schizophrenia. }\end{array}$ & Reeve, 2018 [46] \\
\hline
\end{tabular}


Table 4. Cont

\begin{tabular}{|c|c|c|c|}
\hline & & Main Results Regarding Nightmares & Studies \\
\hline & \multirow{4}{*}{ Symptoms } & \multirow{2}{*}{$\begin{array}{l}\text { - Same themes of delusion and hallucination than in nightmares preceding psychotic } \\
\text { decompensation (two reports) }\end{array}$} & Levin, 1998 [39] \\
\hline & & & Fennig, 1992 [38] \\
\hline & & $\begin{array}{l}\text { - No significant correlations between depressive symptoms (assessed with BDI) and } \\
\text { nightmare frequency } \\
\text { - No significant correlations between psychotic symptoms (assessed with PANNS) and } \\
\text { nightmare frequency }\end{array}$ & Michels, 2014 [41] \\
\hline & & $\begin{array}{l}\text { - Nightmare distress, rather than frequency, is the best marker for the association } \\
\text { between nightmares and daytime impairment: significant correlations between nightmare } \\
\text { distress and delusional severity, depression, anxiety, and stress. }\end{array}$ & Sheaves, 2015 [43] \\
\hline & Suicide & $\begin{array}{l}\text { - Patients with frequent nightmares }{ }^{* *} \text { have more lifetime of suicide history and increase } \\
\text { risk of suicide attempts }\end{array}$ & Li, $2016[45]$ \\
\hline & Treatment & $\begin{array}{l}\text { - Efficacy of treatment by desensitization (one report) } \\
\text { - Improvement of IRT on emotional response, not on nightmare frequency }\end{array}$ & $\begin{array}{l}\text { Shorkey, } 1974[37] \\
\text { Sheaves, } 2015[42]\end{array}$ \\
\hline & & $\begin{array}{l}\text { - Imagery focused cognitive behavioral therapy: large effect size reductions in } \\
\text { nightmares and insomnia post treatment (4 weeks) }\end{array}$ & Sheave, 2019 [47] \\
\hline \multirow{4}{*}{ Comparing studies } & Frequency & $\begin{array}{l}\text { - Significantly more frequent in psychiatric patients (schizophrenia and MDD) than } \\
\text { healthy controls } \\
\text { - No significant differences between patients with schizophrenia and MDD }\end{array}$ & Mume, 2009 [25] \\
\hline & \multirow{3}{*}{ Suicide } & $\begin{array}{l}\text { - Higher suicidality scores (assessed with SUAS) in patients with frequent nightmares } \\
\text { than without (MDD, schizophrenia) }\end{array}$ & Sjöström, 2007 [48] \\
\hline & & $\begin{array}{l}\text { - Patients with more than one past suicide attempts had more frequent nightmares**** } \\
\text { than those with first suicide attempts }\end{array}$ & Sjöström, 2009 [19] \\
\hline & & $\begin{array}{l}\text { - Patients who reported monthly to weekly nightmares were younger and more likely to } \\
\text { have been hospitalized for a recent suicide attempt. } \\
\text { - Severe hopelessness more frequent in patients with nightmares }\end{array}$ & Lamis, 2018 [49] \\
\hline
\end{tabular}


Nightmares were found to be associated with higher suicidality in several studies, including suicidal ideations and attempts, in patients with mood disorders [23,31,32,35,36], or psychotic disorders [45]. In the general population, nightmares are also associated with a higher risk of suicidal thoughts, suicide attempts, or death by suicide [19-21]. Moreover, several studies found frequent co-occurrence of insomnia and nightmares. Insomnia is one of the most common comorbid sleep disorders associated with psychiatric disorders [51,52], and is by itself associated with a higher risk of suicidal ideation in healthy and psychiatric populations [53]. Whereas insomnia is much more often screened for by psychiatrists, being a core symptom in the classification of some psychiatric disorders such as MDD or Bipolar disorder [16], the identification of nightmares is rare and is not included in mood or psychotic disorders classification. In this context, practitioners frequently consider nightmares and disturbing dreams as secondary symptoms, with no predicting or therapeutic relevance. However, even if most of the studies assessing nightmares and suicide are cohorts or case series, and that controlled studies are needed to clarify the role of nightmares on suicidal behavior, the present review suggests that patients should be systematically screened for recurrent or frequent nightmares, as they are both very frequent and seem to be associated with a higher risk of suicide $[15,34,44,45,54]$.

The correlation between nightmares and intensity of symptoms in mood disorders or psychotic disorders is not clear. Indeed, rather than nightmare frequency, nightmare distress may be more specifically associated with psychotic and depressive symptoms [42]. No studies have reported relationships between nightmare distress and depressive symptoms in patients with MDD, nor the relationship between nightmare distress and suicidality in patients with MDD or psychotic disorders. In the general population, nightmares have been associated with hallucinatory experiences [55] and with psychotic-like experiences [46-56].

We decided to exclude all studies with patients under 18 years old because nightmares are more common in children and teenagers, and to avoid potential confusion factors. Nevertheless, one longitudinal study [57] interestingly found that nightmares at 12 years old were a significant predictor of psychotic experiences at 18 years old, after adjustment for possible confounders. This report is in line with our observations previously mentioned. Moreover, Michels et al. found that ARMS patients had more frequent nightmares than healthy controls [41], suggesting that nightmares may be present at a very early stage of the disease.

The exact pathophysiology of nightmares in patients with mood and psychotic disorders is not entirely known. In a recent review, Gieselman et al. hypothesized the etiology of nightmares by hyperarousal and impaired fear extinction, with facilitating factors such as traumatic experiences and childhood adversity, trait susceptibility, maladaptive cognitive factors, and physiological factors [58]. Levin et al. proposed that nightmares reflect problems with the fear extinction function of dreaming [10]. Schredl et al. propose that certain nightmare themes, such as suicide, are of particular interest because they may be related to the psychopathology of waking life [59]. Further studies are expected to better unravel these physio-pathologies and specificities in psychiatric disorders, since nightmares in the context of trauma, stress, delirium, anxiety, or depressed mood may have different pathways and causes.

\subsection{Clinical and Therapeutic Implications}

Suicide, which is the first cause of death among young people, is associated with several modifiable or non-modifiable risk factors, so it is important to be able to identify and manage [17]. Nightmares have been identified as one of the modifiable risk factors for suicide, with specific treatments, such as Image Rehearsal Therapy or Systematic Desensitization and Progressive Deep Muscle Relaxation training for treatment of idiopathic nightmares, or Prazosin if nightmares are associated with of Posttraumatic Stress Disorder (PTSD) [58,60]. Furthermore, as mentioned above, nightmares may be associated with early stages of psychotic or mood disorders, and its treatment may prevent the conversion to a full psychiatric disorder. 


\subsection{Limitations}

This work clearly emphasizes a need to use standardized definitions of nightmares across studies, as we observed a lack of consensus criterion. Indeed, "frequent nightmare" was differently defined from one study to another, and sometimes not defined at all. With our code with asterisks (from * to ${ }^{* * * *}$ when no definitions were proposed, see our methods), we tried to clarify this issue. We plead for standardized use of either the DSM-5 definition or systematic use of published questionnaires such as the Mannheim Dream Questionnaire (MADRE) [60]. DSM-5 defines a mild nightmare disorder as less than one episode per week on average, a moderate disorder as one or more episodes per week, but less than nightly, and a severe disorder as nightly episodes. An acute episode has a duration of 1 month or less, a sub-acute episode a duration between 1 to 6 months, and chronic nightmares endure for 6 months or longer (APA, 2013). Instruments to assess nightmare frequency and nightmare distress exist such as the Nightmare Frequency Questionnaire (NFQ) [61] or the MADRE [60]. The use of such instruments should be more generalized.

Some caveats and limitations of the existing scientific literature reviewed here should be emphasized. First, most studies of nightmares and mood disorders [62] assessed major depressive disorders (MDD), without any information about the unipolar of bipolar subtype of depression. This could bias results; for example, Marinova et al. [22] found a difference in the frequency of nightmares between unipolar and bipolar depression. Patients with unipolar depression and nightmares were more likely to have suicidal thoughts than those without nightmares; this difference was not found in patients with bipolar disorder (although this was a smaller group with underpowered statistics). Second, patients with PTSD or recent trauma were either not screened, nor always excluded from the studies. Yet nightmares are one of the mains symptoms of PTSD and stress-related disorders. This may have been a confounding factors in reported studies [46,48]. Third, there was no information of comorbid personality disorders; as in PTSD it may have been a confounding factor, as it is known that some personality disorders such as borderline personality are more associated with nightmares [2]. Fourth, most cohort studies examined the frequency of nightmares in their patients and looked for an association with suicidality. A significant majority did not report information on the severity of psychiatric symptoms. Patients who had more frequent nightmares were more likely to have suicidal thoughts or attempts but may also have had a higher intensity in their symptoms, which may have led to higher suicidality. Fifth, there was little information about the distinction between bad dreams/nightmares in reported studies. Nightmares are different from bad dreams since nightmares awaken the sleeper [10]. Sixth, only few studies mentioned their patient medication. However, nightmares have been found as being a side effect of some antipsychotics and antidepressant treatments, and so may have been a confounding factor as well [63]. Finally, all the studies were based on clinical evaluation (self-report nightmares or clinician interview), which can have led to a memory bias. There were no laboratory examinations of nightmares with more objective measures (except in the study of Lusignan et al. [40], who explored dreams and not nightmares).

\section{Conclusions}

Nightmares are much more frequent in patients with mood and psychotic disorders than in the general population. Patients with nightmares, compared to those without nightmares, also suffered from more suicidal thoughts and attempts. Little information was available on the association of nightmares and the severity of psychiatric symptoms, and this relationship warrants further investigations. Besides, rather than the frequency of nightmares, it may be the distress associated with nightmares that is correlated with the severity of the psychiatric disorder. Importantly, nightmares seem to respond to specific therapies such as IRT, and further investigations are needed to see if they should be used as add-on treatments and may prevent conversion to full psychiatric disorders or poorer outcomes of existing mood and psychotic disorders. Further studies assessing whether nightmare treatment not only improves patient-sleep perception but also underlying psychiatric diseases are definitively needed. 
Legends: The literature search was performed from PubMed, Cochrane Library and PsycINFO electronic database, using the following terms: ("nightmare" (All Fields) OR "dream" (All Fields) OR "parasomnia" (All Fields) OR "nightmare" (MeSH Terms)) AND ("psychosis" (All Fields) OR "psychosis "(MeSH Terms) OR "hallucination" (All Fields) OR "schizophrenia" (All Fields) OR "bipolar disorder" (All Fields) OR "bipolar disorder" (MeSH Terms) OR “suicide" (All Fields) OR "suicide" (MeSH Terms) OR “depression" (All Fields) OR "major depressive episode" (All Fields) OR "depressive disorder" (All Fields) OR “depressive disorder" (MeSH Terms) OR "manic" (All Fields)).

Author Contributions: M.A.A. and P.A.G. drew the design; M.A.A. and P.A.G. acquired the data; M.A.A. and P.A.G. analyzed the data; M.A.A., M.L., M.-P.d. and P.A.G. wrote the first version; M.A.A., M.L., M.-P.d. and P.A.G. made significant contributions to the paper. All authors have read and agreed to the published version of the manuscript.

Funding: This research received no external funding.

Conflicts of Interest: The authors declare no conflict of interest.

\section{References}

1. Geoffroy, P.A.; Tebeka, S.; Blanco, C.; Dubertret, C.; Le Strat, Y. Shorter and longer durations of sleep are associated with an increased twelve-month prevalence of psychiatric and substance use disorders: Findings from a nationally representative survey of US adults (NESARC-III). J. Psychiatr. Res. 2020, 124, 34-41. [CrossRef] [PubMed]

2. Krakow, B. Nightmare Complaints in Treatment-Seeking Patients in Clinical Sleep Medicine Settings: Diagnostic and Treatment Implications. Sleep 2006, 29, 1313-1319. [CrossRef] [PubMed]

3. Semiz, U.B.; Başoğlu, C.; Ebrinc, S.; Cetin, M. Nightmare disorder, dream anxiety, and subjective sleep quality in patients with borderline personality disorder. Psychiatry Clin. Neurosci. 2008, 62, 48-55. [CrossRef] [PubMed]

4. Pigeon, W.R.; Pinquart, M.; Conner, K. Meta-Analysis of Sleep Disturbance and Suicidal Thoughts and Behaviors. J. Clin. Psychiatry 2012, 73, e1160-e1167. [CrossRef]

5. Li, S.X.; Zhang, B.; Li, A.M.; Wing, Y.K. Prevalence and Correlates of Frequent Nightmares: A CommunityBased 2-Phase Study. Sleep 2010, 33, 774-780. [CrossRef]

6. Sandman, N.; Valli, K.; Kronholm, E.; Ollila, H.M.; Revonsuo, A.; Laatikainen, T.; Paunio, T. Nightmares: Prevalence among the Finnish General Adult Population and War Veterans during 1972-2007. Sleep 2013, 36, 1041-1050. [CrossRef]

7. Janson, C.; Gislason, T.; De Backer, W.; Plaschke, P.; Björnsson, E.; Hetta, J.; Kristbjarnason, H.; Vermeire, P.; Boman, G. Prevalence of sleep disturbances among young adults in three European countries. Sleep 1995, 18, 589-597.

8. Schredl, M. Nightmare frequency and nightmare topics in a representative German sample. Eur. Arch. Psychiatry Clin. Neurosci. 2010, 260, 565-570. [CrossRef]

9. Kerkhof, G.A. Epidemiology of sleep and sleep disorders in The Netherlands. Sleep Med. 2017, 30, $229-239$. [CrossRef]

10. Nielsen, T.; Levin, R. Nightmares: A new neurocognitive model. Sleep Med. Rev. 2007, 11, 295-310. [CrossRef]

11. Forbes, D.; Phelps, A.J.; McHugh, A.F.; Debenham, P.; Hopwood, M.; Creamer, M. Imagery rehearsal in the treatment of posttraumatic nightmares in Australian veterans with chronic combat-related PTSD: 12-month follow-up data. J. Trauma. Stress 2003, 16, 509-513. [CrossRef] [PubMed]

12. Leskin, G.A.; Woodward, S.H.; Young, H.E.; Sheikh, J.I. Effects of comorbid diagnoses on sleep disturbance in PTSD. J. Psychiatr. Res. 2002, 36, 449-452. [CrossRef]

13. Neylan, T.C.; Marmar, C.R.; Metzler, T.J.; Weiss, D.S.; Zatzick, D.F.; Delucchi, K.L.; Wu, R.M.; Schoenfeld, F.B. Sleep Disturbances in the Vietnam Generation: Findings from a Nationally Representative Sample of Male Vietnam Veterans. Am. J. Psychiatry 1998, 155, 929-933. [CrossRef] [PubMed]

14. Levin, R.; Nielsen, T. Disturbed dreaming, posttraumatic stress disorder, and affect distress: A review and neurocognitive model. Psychol. Bull. 2007, 133, 482-528. [CrossRef]

15. Woo, M. Eye Movement Desensitization and Reprocessing Treatment of Nightmares: A Case Report. J. EMDR Pr. Res. 2014, 8, 129-134. [CrossRef]

16. Sateia, M.J. International Classification of Sleep Disorders-Third Edition. Chest 2014, 146, 1387-1394. [CrossRef] 
17. American Psychiatric Association (Ed.) Diagnostic and Statistical Manual of Mental Disorders: DSM-5, 5th ed.; American Psychiatric Association: Washington, DC, USA, 2013.

18. Geoffroy, P.A.; Oquendo, M.; Courtet, P.; Blanco, C.; Olfson, M.; Peyre, H.; Lejoyeux, M.; Limosin, F.; Hoertel, N. Sleep complaints are associated with increased suicide risk independently of psychiatric disorders: Results from a national 3-year prospective study. Mol. Psychiatry 2020, 1-11. [CrossRef]

19. Cukrowicz, K.C.; Otamendi, A.; Pinto, J.V.; Bernert, R.A.; Krakow, B.; Joiner, T.E. The impact of insomnia and sleep disturbances on depression and suicidality. Dreaming 2006, 16, 1-10. [CrossRef]

20. Sjöström, N.; Hetta, J.; Waern, M. Persistent nightmares are associated with repeat suicide attempt. Psychiatry Res. 2009, 170, 208-211. [CrossRef]

21. Tanskanen, A.; Tuomilehto, J.; Viinamäki, H.; Vartiainen, E.; Lehtonen, J.; Puska, P. Nightmares as Predictors of Suicide. Sleep 2001, 24, 845-848. [CrossRef]

22. Littlewood, D.; Gooding, P.A.; Panagioti, M.; Kyle, S.D. Nightmares and Suicide in Posttraumatic Stress Disorder: The Mediating Role of Defeat, Entrapment, and Hopelessness. J. Clin. Sleep Med. 2016, 12, 393-399. [CrossRef] [PubMed]

23. Marinova, P.; Koychev, I.; Laleva, L.; Kancheva, L.; Tsvetkov, M.; Bilyukov, R.; Vandeva, D.; Felthouse, A.; Koychev, G. Nightmares and suicide: Predicting risk in depression. Psychiatr. Danub. 2014, 26, 159-164. [PubMed]

24. Ribeiro, J.D.; Yen, S.; Joiner, T.; Siegler, I.C. Capability for suicide interacts with states of heightened arousal to predict death by suicide beyond the effects of depression and hopelessness. J. Affect. Disord. 2015, 188, 53-59. [CrossRef] [PubMed]

25. Horwitz, A.G.; Berona, J.; Czyz, E.K.; Yeguez, C.E.; King, C.A. Positive and Negative Expectations of Hopelessness as Longitudinal Predictors of Depression, Suicidal Ideation, and Suicidal Behavior in High-Risk Adolescents. Suicide Life-Threat. Behav. 2017, 47, 168-176. [CrossRef]

26. Mume, C.O. Nightmare in schizophrenic and depressed patients. Eur. J. Psychiatry 2009, 23, 177-183. [CrossRef]

27. Koffel, E.; Watson, D. Unusual sleep experiences, dissociation, and schizotypy: Evidence for a common domain. Clin. Psychol. Rev. 2009, 29, 548-559. [CrossRef] [PubMed]

28. Moher, D.; Liberati, A.; Tetzlaff, J.; Altman, D.G. For the PRISMA Group Preferred reporting items for systematic reviews and meta-analyses: The PRISMA statement. BMJ 2009, 339, b2535. [CrossRef]

29. World Health Organization. International Classification of Diseases for Mortality and Morbidity Statistics, (11th Revision); WHO: Geneva, Switzerland, 2018.

30. Ağargün, M.Y.; Cilli, A.S.; Kara, H.; Tarhan, N.; Kincir, F.; Oz, H. Repetitive and frightening dreams and suicidal behavior in patients with major depression. Compr. Psychiatry 1998, 39, 198-202. [CrossRef]

31. Agargun, M.Y.; Besiroglu, L.; Cilli, A.S.; Güleç, M.; Aydin, A.; Inci, R.; Selvi, Y. Nightmares, suicide attempts, and melancholic features in patients with unipolar major depression. J. Affect. Disord. 2007, 98, 267-270. [CrossRef]

32. Besiroglu, L.; Agargun, M.Y.; Inci, R. Nightmares and terminal insomnia in depressed patients with and without melancholic features. Psychiatry Res. 2005, 133, 285-287. [CrossRef]

33. Thünker, J.; Pietrowsky, R. Effectiveness of a manualized imagery rehearsal therapy for patients suffering from nightmare disorders with and without a comorbidity of depression or PTSD. Behav. Res. Ther. 2012, 50, 558-564. [CrossRef] [PubMed]

34. Li, S.X.; Lam, S.P.; Chan, J.W.Y.; Yu, M.W.M.; Wing, Y.-K. Residual Sleep Disturbances in Patients Remitted From Major Depressive Disorder: A 4-Year Naturalistic Follow-up Study. Sleep 2012, 35, 1153-1161. [CrossRef] [PubMed]

35. Lai, Y.-C.; Huang, M.-C.; Chen, H.-C.; Lu, M.-K.; Chiu, Y.-H.; Shen, W.W.; Lu, R.-B.; Kuo, P.-H. Familiality and clinical outcomes of sleep disturbances in major depressive and bipolar disorders. J. Psychosom. Res. 2014, 76, 61-67. [CrossRef] [PubMed]

36. Agargun, M.Y.; Kara, H.; Inci, R. Nightmares associated with the onset of mania: Three case reports. Sleep Hypn. 2003, 5, 192-196.

37. Li, S.X.; Lam, S.P.; Zhang, J.; Yu, M.W.M.; Chan, J.W.Y.; Chan, C.S.Y.; Espie, C.A.; Freeman, D.; Mason, O.; Wing, Y.K. Sleep Disturbances and Suicide Risk in an 8-Year Longitudinal Study of Schizophrenia-Spectrum Disorders. Sleep 2016, 39, 1275-1282. [CrossRef]

38. Reeve, S.; Sheaves, B.; Freeman, D. Sleep Disorders in Early Psychosis: Incidence, Severity, and Association with Clinical Symptoms. Schizophr. Bull. 2019, 45, 287-295. [CrossRef] 
39. Fennig, S.; Salganik, E.; Chayat, M. Psychotic Episodes and Nightmares: A Case Study. J. Nerv. Ment. Dis. 1992, 180, 60. [CrossRef]

40. Levin, R. Nightmares and Schizotypy. Psychiatry 1998, 61, 206-216. [CrossRef]

41. Lusignan, F.-A.; Zadra, A.; Dubuc, M.-J.; Daoust, A.-M.; Mottard, J.-P.; Godbout, R. Dream content in chronically-treated persons with schizophrenia. Schizophr. Res. 2009, 112, 164-173. [CrossRef]

42. Michels, F.; Schilling, C.; Rausch, F.; Eifler, S.; Zink, M.; Meyer-Lindenberg, A.; Schredl, M. Nightmare frequency in schizophrenic patients, healthy relatives of schizophrenic patients, patients at high risk states for psychosis, and healthy controls. Int. J. Dream Res. 2014, 7, 9-13.

43. Sheaves, B.; Onwumere, J.; Keen, N.; Stahl, D.; Kuipers, E. Nightmares in Patients with Psychosis: The Relation with Sleep, Psychotic, Affective, and Cognitive Symptoms. Can. J. Psychiatry 2015, 60, 354-361. [CrossRef] [PubMed]

44. Shorkey, C.; Himle, D.P. Systematic desensitization treatment of a recurring nightmare and related insomnia. J. Behav. Ther. Exp. Psychiatry 1974, 5, 97-98. [CrossRef]

45. Sheaves, B.; Onwumere, J.; Keen, N.; Kuipers, E. Treating your worst nightmare: A case-series of imagery rehearsal therapy for nightmares in individuals experiencing psychotic symptoms. Cogn. Behav. Ther. 2015, 8. [CrossRef]

46. Sheaves, B.; Porcheret, K.; Tsanas, A.; Espie, C.A.; Foster, R.G.; Freeman, D.; Harrison, P.J.; Wulff, K.; Goodwin, G.M. Insomnia, Nightmares, and Chronotype as Markers of Risk for Severe Mental Illness: Results from a Student Population. Sleep 2016, 39, 173-181. [CrossRef]

47. Sheaves, B.; Holmes, E.A.; Rek, S.; Taylor, K.M.; Nickless, A.; Waite, F.; Germain, A.; Espie, C.A.; Harrison, P.J.; Foster, R.; et al. Cognitive Behavioural Therapy for Nightmares for Patients with Persecutory Delusions (Nites): An Assessor-Blind, Pilot Randomized Controlled Trial. Can. J. Psychiatry 2019, 64, 686-696. [CrossRef]

48. Sjöström, N.; Waern, M.; Hetta, J. Nightmares and Sleep Disturbances in Relation to Suicidality in Suicide Attempters. Sleep 2007, 30, 91-95. [CrossRef]

49. Lamis, D.A.; Innamorati, M.; Erbuto, D.; Berardelli, I.; Montebovi, F.; Serafini, G.; Amore, M.; Krakow, B.; Girardi, P.; Pompili, M. Nightmares and suicide risk in psychiatric patients: The roles of hopelessness and male depressive symptoms. Psychiatry Res. 2018, 264, 20-25. [CrossRef]

50. Hombali, A.; Seow, E.; Yuan, Q.; Chang, S.H.S.; Satghare, P.; Kumar, S.; Verma, S.K.; Mok, Y.M.; Chong, S.A.; Subramaniam, M. Prevalence and correlates of sleep disorder symptoms in psychiatric disorders. Psychiatry Res. 2019, 279, 116-122. [CrossRef]

51. Khurshid, K.A. Comorbid Insomnia and Psychiatric Disorders: An Update. Innov. Clin. Neurosci. 2018, 15, 28-32. [PubMed]

52. Geoffroy, P.A.; Hoertel, N.; Etain, B.; Bellivier, F.; Delorme, R.; Limosin, F.; Peyre, H. Insomnia and hypersomnia in major depressive episode: Prevalence, sociodemographic characteristics and psychiatric comorbidity in a population-based study. J. Affect. Disord. 2018, 226, 132-141. [CrossRef] [PubMed]

53. Richardson, J.D.; Thompson, A.; King, L.; Corbett, B.; Shnaider, P.; Cyr, K.S.; Nelson, C.; Sareen, J.; Elhai, J.D.; Zamorski, M. Insomnia, psychiatric disorders and suicidal ideation in a National Representative Sample of active Canadian Forces members. BMC Psychiatry 2017, 17, 1-10. [CrossRef] [PubMed]

54. Nadorff, M.R.; Lambdin, K.K.; Germain, A. Pharmacological and non-pharmacological treatments for nightmare disorder. Int. Rev. Psychiatry 2014, 26, 225-236. [CrossRef] [PubMed]

55. Rek, S.; Sheaves, B.; Freeman, D. Nightmares in the general population: Identifying potential causal factors. Soc. Psychiatry Psychiatr. Epidemiol. 2017, 52, 1123-1133. [CrossRef] [PubMed]

56. Andorko, N.D.; Millman, Z.B.; Klingaman, E.A.; Medoff, D.; Kline, E.R.; Devylder, J.E.; Reeves, G.; Schiffman, J. Association between sleep, childhood trauma and psychosis-like experiences. Schizophr. Res. 2018, 199, 333-340. [CrossRef] [PubMed]

57. Thompson, A.; Lereya, S.T.; Lewis, G.; Zammit, S.; Fisher, H.L.; Wolke, D. Childhood sleep disturbance and risk of psychotic experiences at 18: UK birth cohort. Br. J. Psychiatry 2015, 207, 23-29. [CrossRef]

58. Gieselmann, A.; Aoudia, M.A.; Carr, M.; Germain, A.; Gorzka, R.; Holzinger, B.; Kleim, B.; Krakow, B.; Kunze, A.E.; Lancee, J.; et al. Aetiology and treatment of nightmare disorder: State of the art and future perspectives. J. Sleep Res. 2019, 28, e12820. [CrossRef]

59. Schredl, M.; Göritz, A.S. Nightmare Themes: An Online Study of Most Recent Nightmares and Childhood Nightmares. J. Clin. Sleep Med. 2018, 14, 465-471. [CrossRef] 
60. Nisha, A.R.; Rochelle, S.Z.; Sanford, H.A.; Kenneth, R.C.; Susmita, C.; Anoop, K.; Rama, K.M.; Kannan, R.; David, A.K.; Sabin, R.B.; et al. Best practice guide for the treatment of nightmare disorder in adults. J. Clin. Sleep Med. 2010, 6, 389-401.

61. Schredl, M. The Mannheim Dream Questionnaire (MADRE): Retest reliability, age and gender effects. Int. J. Dream Res. 2014, 7, 141-147.

62. Krakow, B.; Schrader, R.; Tandberg, D.; Hollifield, M.; Koss, M.P.; Yau, C.; Cheng, D.T. Nightmare frequency in sexual assault survivors with PTSD. J. Anxiety Disord. 2002, 16, 175-190. [CrossRef]

63. Wichniak, A.; Wierzbicka, A.; Walęcka, M.; Jernajczyk, W. Effects of Antidepressants on Sleep. Curr. Psychiatry Rep. 2017, 19, 1-7. [CrossRef] [PubMed]

Publisher's Note: MDPI stays neutral with regard to jurisdictional claims in published maps and institutional affiliations.

(C) 2020 by the authors. Licensee MDPI, Basel, Switzerland. This article is an open access article distributed under the terms and conditions of the Creative Commons Attribution (CC BY) license (http://creativecommons.org/licenses/by/4.0/). 